Tomasz Dubowski

\title{
GRANICA POLSKO-ROSYJSKA JAKO GRANICA ZEWNĘTRZNA UNII EUROPEJSKIEJ
}

\section{Uwagi wstępne}

Granice państwowe jako wytyczone w określony sposób linie wyznaczają zakres zwierzchnictwa terytorialnego państw ${ }^{1}$. Jako takie oddzielają nie tylko obszary władztwa państwowego, systemy prawne, lecz również określone społeczności. Państwa jako podmioty suwerenne, samodzielnie - o ile umowy międzynarodowe nie stanowią inaczej - ustanawiaja reguły ruchu osobowego i towarowego przez własne granice ${ }^{2}$ oraz organizują ochronę owych granic ${ }^{3}$. Ich (granic) funkcjonowanie, zasady ich przekraczania, ochrony oraz zarządzania nimi determinują zatem, do pewnego stopnia, kształt relacji między społecznościami zamieszkującymi po obu ich stronach - tak w aspekcie gospodarczym, ekonomicznym, jak i czysto ludzkim.

Granice w sposób naturalny kojarzą się z istnieniem państw. Rozpatrywanie problemu granic wewnętrznych i zewnętrznych w kontekście organizacji międzynarodowych jest raczej czymś rzadkim. Unia Europejska jest w tej mierze wyjątkiem. Dlaczego akurat w wypadku UE zagadnienie jej granic jest aż tak istotne? Odpowiedzią - najkrótszą z możliwych - wydaje się zakres kompetencji Unii i jej szczególny, ponadnarodowy charakter. Ukształtowanie w ramach Unii pogłębionych form kooperacji międzypaństwowej w różnych dziedzinach spowodowało, iż koniecznym stało się sięgnięcie do pojęcia „granic zewnętrznych” (i wewnętrznych) UE. Niezbędnym stało się bowiem ustalenie zakresu obowiązywania w przestrzeni zasad takich jak fundamentalne swobody rynku wewnętrznego (m.in. swobodny przepływ towarów). Podobnie koniecznym okazało się ustalenie granic unijnej przestrzeni wolności, bezpieczeństwa i sprawiedliwości (wraz z zagwarantowaną w jej ramach swobodą przepływu osób). W rezultacie pojęcie „granic zewnętrznych” Unii obecne

\footnotetext{
W niniejszym opracowaniu odnoszę się do granic lądowych.

W. Góralczyk, S. Sawicki, Prawo międzynarodowe publiczne w zarysie, Warszawa 2004, s. 187-188.

Por. ustawa z dnia 12 października 1990 r. o ochronie granicy państwowej, tekst jedn. Dz.U. z 2009 r. Nr 12, poz. 67.
} 
jest już w samym unijnym prawie pierwotnym i tym samym przestaje być wyłącznie skrótem myślowym.

Fakt, iż do problemu granic zewnętrznych Unii odnoszą się określone regulacje prawa UE (pierwotnego i wtórnego), powoduje, iż konsekwencje członkostwa Polski w UE widoczne są także w zakresie statusu polskich granic państwowych oraz zasad i reguł ich przekraczania czy ochrony. W tym obszarze należy podkreślić, iż funkcjonowanie polskich granic państwowych podlega obecnie nie tylko odpowiednim regulacjom krajowym, ale i właściwym regulacjom unijnym. Jest to szczególnie istotne w wypadku - postrzeganych w szerokim aspekcie - stosunków polsko-rosyjskich. Zauważmy, iż granica Polski z Rosją jest granicą zewnętrzną Unii Europejskiej, co nadaje jej szczególny status, a jednocześnie znaczenie Rosji jako partnera Polski (i samej UE) jest niezwykle doniosłe.

Celem niniejszego opracowania jest przybliżenie - na tle specyfiki UE i jej porządku prawnego - istoty pojęcia „granic zewnętrznych Unii Europejskiej” z uwzględnieniem przykładu granicy polsko-rosyjskiej i konsekwencji, jakie w tym obszarze wynikają dla Polski z faktu członkostwa w UE. Szczegółowe kwestie dotyczące funkcjonowania granicy z Rosją zostaną przedstawione w innych fragmentach tego tomu. W poniższych rozważaniach granica polsko-rosyjska zostanie zatem potraktowana jako ilustracja pewnego fenomenu - granicy państwowej stanowiącej jednocześnie granicę zewnętrzną szczególnego typu organizacji międzynarodowej (UE). Ukazanie wskazanego zagadnienia wymaga omówienia specyfiki Unii Europejskiej i stanowionego przez nią prawa, problematyki granic wewnętrznych i zewnętrznych Unii Europejskiej wraz z podstawowymi regulacjami prawnymi w tej materii, kwestii granicy polsko-rosyjskiej jako granicy państwowej oraz podstawowych konsekwencji członkostwa Polski w UE dla funkcjonowania owej granicy.

\section{Szczególny charakter Unii Europejskiej jako organizacji międzynarodowej a problem jej granic}

Pojęcie „granic wewnętrznych” i ,granic zewnętrznych” Unii Europejskiej nie jest pojęciem umownym, pozbawionym wymiaru prawnego. Zagadnienia dotyczące obu kategorii uregulowane są zarówno w traktatach stanowiących podstawę Unii (Traktat o Unii Europejskiej, dalej TUE ${ }^{4}$ oraz Traktat o funkcjonowaniu Unii Europejskiej, dalej TFUE ${ }^{5}$ ), jak i w aktach unijnego prawa wtórnego. Z punktu widzenia państw członkowskich sytuacja ta ma poważne implikacje. Na tym tle warto poczynić następujące uwagi.

$4 \quad$ Traktat o Unii Europejskiej, Dz.U. UE C 83 z 30 marca 2010 r. (wersja skonsolidowana).

5 Traktat o funkcjonowaniu Unii Europejskiej, Dz.U. UE C 83 z 30 marca 2010 r. (wersja skonsolidowana). 
Przede wszystkim należy wskazać, iż stopień zaawansowania procesów integracyjnych w ramach Unii Europejskiej pozwala nazywać ją szczególnym typem organizacji międzynarodowej - tj. organizacją ponadnarodową ${ }^{6}$. Wśród elementów charakteryzujących ten typ organizacji międzynarodowej wymienić należy m.in. szeroki zakres ich kompetencji oraz szczególne cechy stanowionego przez nie prawa. W wypadku UE są to specyficzne zasady stosowania prawa Unii - prymat względem prawa krajowego oraz skutek bezpośredni norm prawa unijnego. Obie zasady powodują, iż unijna legislacja korzysta z pierwszeństwa w przypadku kolizji z prawem krajowym (tzw. pierwszeństwo stosowania), zaś podmioty prywatne (osoby fizyczne i prawne) - przy zaistnieniu określonych przesłanek - mogą na przepisy prawa UE powoływać się bezpośrednio przed organami krajowymi. Warto też dodać, iż istota poszczególnych aktów prawa wtórnego Unii (przede wszystkim rozporządzeń i dyrektyw) powoduje, iż unijna legislacja (normy tworzone przez instytucje UE) stają się częścią porządków prawnych państw członkowskich. A ponieważ legislacja unijna obejmuje szereg dziedzin wiążących się z funkcjonowaniem granic państw członkowskich (wewnętrznych i zewnętrznych granic UE), dla reżimu granicznego owych państw ma to niebagatelne znaczenie.

Po drugie należy podkreślić, iż stopień „ingerencji” Unii Europejskiej w poszczególne sfery działalności państw członkowskich wynika z zakresu przyznanych jej kompetencji. Jest on, co charakterystyczne dla organizacji ponadnarodowej, niezwykle szeroki. Jednocześnie, na mocy ostatniej reformy Unii ${ }^{7}$, doszło do ciekawej klasyfikacji jej kompetencji. Ujmując rzecz w niezbędnym skrócie, pewne dziedziny podlegają wyłącznej kompetencji UE, co oznacza, iż w obszarach tych (m.in. unia celna, polityka pieniężna w strefie euro) wyłącznie Unia może przyjmować akty prawnie wiążące. W określonych dziedzinach Unia dzieli kompetencje z państwami członkowskimi (m.in. rynek wewnętrzny, przestrzeń wolności, bezpieczeństwa i sprawiedliwości), co oznacza, iż zarówno Unia, jak i owe państwa mogą w tych obszarach stanowić prawo i przyjmować akty prawnie wiążące. Jednak państwa członkowskie mogą z tej kompetencji skorzystać jedynie w zakresie, w jakim Unia nie skorzystała bądź postanowiła zaprzestać wykonywania swojej kompetencji. Przyjęte rozwiązanie oznacza, iż w pewnych dziedzinach państwa członkowskie pozbawione są w ogóle możliwości stanowienia aktów prawnie wiążących (chyba że stanowią je $\mathrm{z}$ upoważnienia Unii lub w celu wykonania aktów Unii). W innych obszarach z kolei państwa moga prawo stanowić, o ile jednak ze swych kompetencji prawodawczych nie skorzystała UE (lub postanowiła się z ich wykonywania wycofać). Reguły te będą znajdowały zastosowanie również w materiach związanych z funkcjonowaniem wewnętrznych i zewnętrznych granic Unii Europejskiej. Za-

6

Por. m.in. M.M. Kenig-Witkowska (red.), Prawo instytucjonalne Unii Europejskiej, Warszawa 2007, s. 32. Por. Traktat z Lizbony zmieniający Traktat o Unii Europejskiej i Traktat ustanawiający Wspólnotę Europejską podpisany w Lizbonie dnia 13 grudnia 2007 r., Dz.U. UE C 306 z 17 grudnia 2007 r. 
uważmy m.in., iż dziedzina, której podstawą i istotą jest problem granic zewnętrznych Unii, jest „przestrzeń wolności, bezpieczeństwa i sprawiedliwości” stanowiąca przedmiot kompetencji dzielonych między UE i państwa członkowskie.

Wreszcie z całą mocą należy podkreślić, iż zakres integracji państw członkowskich w ramach Unii Europejskiej w ostatnich dekadach znacznie wykroczył poza wymiar stricte gospodarczy i ekonomiczny. Dziś Unia zakresem swych kompetencji obejmuje również kwestie polityki społecznej, środowiska naturalnego, zdrowia publicznego, a nawet (jakkolwiek w ograniczonym zakresie i z różnym skutkiem) polityki zagranicznej i bezpieczeństwa. W ten sposób integracja w ramach Unii ma obecnie wymiar gospodarczy, polityczny i społeczny. Zauważmy, iż z punktu widzenia reżimu granicznego Unii Europejskiej i państw członkowskich ów szeroki zakres kompetencji UE ma znaczenie fundamentalne. Wątek granic - wewnętrznych i zewnętrznych - UE obecny jest (mniej bądź bardziej bezpośrednio) w częściach Traktatów poświęconych różnym dziedzinom. W efekcie prawo unijne może odnosić się do sfery granic niekoniecznie wprost, a również poprzez regulacje dotyczące całej gamy obszarów aktywności Unii.

Uwzględniając powyższą charakterystykę samej UE i jej porządku prawnego, należy stwierdzić, iż kompetencje UE mogą (również pośrednio) i w różnych wymiarach „dotykać” kwestii granic państw członkowskich i (zależnie od kategorii kompetencji Unii) w różnym stopniu ograniczać swobodę owych państw w tej materii. Co więcej, regulacje unijne w obszarach związanych z funkcjonowaniem granic (traktatowe czy wtórne) stają się częścią krajowych porządków prawnych, a w przypadku kolizji z normami wewnętrznymi korzystają z atrybutu pierwszeństwa. Oznacza to, iż w określonych aspektach regulowanie reżimu granicznego jest efektem woli „ustawodawcy” unijnego, nie krajowego.

Główne elementy regulacji traktatowej oraz prawa wtórnego UE odnoszące się do problemu jej granic zostaną zatem przedstawione poniżej. Pozwoli to dostrzec zagadnienie granic wewnętrznych i zewnętrznych Unii Europejskiej we właściwym kontekście.

\section{Granice wewnętrzne i zewnętrzne Unii Europejskiej}

We wprowadzeniu sygnalizowano już, że analiza problemu granic zewnętrznych (i wewnętrznych) w odniesieniu do państw jest rzeczą naturalną. W przypadku Unii Europejskiej jako organizacji międzynarodowej rozpatrywanie tej kwestii znajduje uzasadnienie w zakresie jej kompetencji i specyfice stanowionego przez nią prawa. 
Obszar UE w swym wymiarze wewnętrznym i zewnętrznym (bez bezpośredniego odwołania do pojęcia ,granic”) pojawia się dla przykładu już na poziomie unii celnej. W art. 30 TFUE wskazano, iż cła przywozowe i wywozowe są zakazane między Państwami Członkowskimi przy jednoczesnym postanowieniu (art. 31 TFUE), iż Rada określa cła wspólnej taryfy celnej, stanowiąc na wniosek Komisji. Mimo iż w żadnym z cytowanych przepisów pojęcie ,granica” nie pojawia się, wyraźnie wynika z nich, iż w zakresie opłat celnych inne zasady obowiązują między państwami członkowskimi (granice wewnętrzne), a inne w relacjach z państwami trzecimi (wspólna taryfa celna w wymiarze zewnętrznym) ${ }^{8}$.

Znaczenie granic zewnętrznych Unii Europejskiej w sposób dobitny podkreślają przepisy TFUE w zakresie wzmiankowanej wyżej przestrzeni wolności, bezpieczeństwa i sprawiedliwości UE (art. 3 ust. 2 TUE, Tytuł V TFUE). Temu zagadnieniu należy poświęcić więcej miejsca.

Przede wszystkim należy podkreślić, iż zgodnie z art. 3 ust. 2 TUE Unia zapewnia swoim obywatelom przestrzeń wolności, bezpieczeństwa i sprawiedliwości bez granic wewnętrznych (wszelkie podkreślenia w tekście pochodzą od autora), $w$ której zagwarantowana jest swoboda przepływu osób, w powiqzaniu z właściwymi środkami w odniesieniu do kontroli granic zewnętrznych, azylu, imigracji, jak również zapobiegania i zwalczania przestępczości. Innymi słowy, jednym z celów UE jest ustanowienie przestrzeni bez granic wewnętrznych, której bezpieczeństwo (wolność i sprawiedliwość) chronione będzie poprzez określone instrumenty kontroli granic zewnętrznych Unii (oraz odpowiednimi środkami w zakresie azylu, imigracji czy zapobiegania przestępczości).

Kompetencje Unii w zakresie przestrzeni wolności, bezpieczeństwa i sprawiedliwości zostały sprecyzowane w Tytule V TFUE. W odniesieniu do granic zewnętrznych UE, w art. 67 ust. 2 TFUE wskazano, iż Unia zapewnia brak kontroli osób na granicach wewnętrznych i rozwija wspólnq polityke w dziedzinie azylu, imigracji i kontroli granic zewnętrznych, oparta na solidarności między Państwami Członkowskimi i sprawiedliwa wobec obywateli państw trzecich [...]. Obszar „wewnątrz” Unii jest zatem obszarem, na którym kontrole graniczne - co do zasady - nie obowiązują. Jednocześnie wynikające z tego rozwiązania zagrożenia dla wolności, bezpieczeństwa i sprawiedliwości wewnątrz UE rekompensowane są rozwojem i realizacją unijnej polityki w zakresie azylu, imigracji i - co z naszego punktu widzenia najważniejsze - kontroli granic zewnętrznych.

W ostatniej z wymienionych dziedzin działania Unii Europejskiej koncentrują się wokół (art. 77 ust. 1 TFUE): 
- zapewnienia braku jakiejkolwiek kontroli osób, niezależnie od ich obywatelstwa, przy przekraczaniu przez nie granic wewnętrznych,

- zapewnienia kontroli osób i skutecznego nadzoru przy przekraczaniu granic zewnętrznych,

- stopniowego wprowadzania zintegrowanego systemu zarządzania granicami zewnętrznymi.

W powyższym zakresie instytucje Unii (Parlament Europejski i Radę) wyposażono w kompetencję do przyjmowania regulacji dotyczących:

- wspólnej polityki w zakresie wiz i innych dokumentów uprawniających do krótkiego pobytu,

- kontroli, którym podlegają osoby przekraczające granice zewnętrzne,

- warunków swobodnego przemieszczania się obywateli państw trzecich, w krótkim okresie, na terytorium Unii,

- wszelkich środków niezbędnych dla stopniowego wprowadzania zintegrowanego systemu zarządzania granicami zewnętrznymi,

- braku jakiejkolwiek kontroli osób, niezależnie od ich obywatelstwa, przy przekraczaniu przez nie granic wewnętrznych

Warto jednak dodać, iż Unia nie ingeruje w sferę kompetencji państw członkowskich $w$ odniesieniu do geograficznego wytyczania ich granic, zgodnie z prawem międzynarodowym (art. 77 ust. 4 TFUE). Warto również odnotować, iż przestrzeń wolności, bezpieczeństwa i sprawiedliwości jako obszar działalności UE mieści się w ramach kompetencji dzielonych miedzy Unię a państwa członkowskie. Oznacza to, przypomnijmy, iż w tej dziedzinie państwa członkowskie mogą stanowić prawo i przyjmować akty prawnie wiążące jedynie w takim zakresie, w jakim swych kompetencji prawodawczych nie wykonała Unia Europejska (bądź z ich wykonywania się wycofała). Zauważmy, iż ogranicza to (czy też może ograniczać) w sposób istotny swobodę państw w regulowaniu takich kwestii, jak m.in. polityka wizowa, zarządzania granicami czy wreszcie osobowe kontrole graniczne. Jeżeli bowiem Unia w obszarze swego reżimu granicznego przyjmie określone przepisy, państwa członkowskie podlegają im z zachowaniem zasad wskazanych w punkcie drugim (prymat, skutek bezpośredni) i nie moga podejmować indywidualnych środków w tej mierze (chyba że takie uprawnienie wynika z norm prawa UE).

Unia Europejska - dążąc do realizacji celów przewidzianych traktatowo i korzystając z przyznanych jej kompetencji - przyjęła szereg przepisów (łącznie z zawarciem umów międzynarodowych z państwami trzecimi) regulujących zagad- 
nienia wskazane wyżej i przesądzających o formule unijnego reżimu granicznego. Wybranym regulacjom prawa wtórnego należy przyjrzeć się bliżej, odnosząc ich treść do funkcjonowania granicy polsko-rosyjskiej. Należy również ukazać sposób kształtowania się obecnej granicy między Polską a Rosją.

\section{Od granicy Polski ze Związkiem Radzieckim do granicy z Federacją Rosyjską}

Proces kształtowania się polskiej granicy państwowej po drugiej wojnie światowej - na każdym w zasadzie z jej odcinków - był procesem niezwykle ciekawym. $\mathrm{Z}$ racji istnienia dwóch państw niemieckich wiele kontrowersji budziło wyznaczenie i uznanie polskiej granicy zachodniej ${ }^{9}$. Granica wschodnia Polski, zwłaszcza uwzględniając doświadczenia lat międzywojennych oraz trzech ostatnich dekad, również przeszła istotną i interesującą ewolucję.

Dzisiejsza granica polsko-rosyjska to fragment ukształtowanej po drugiej wojnie granicy Polski ze Związkiem Socjalistycznych Republik Radzieckich (ZSRR). Jej przebieg został ustalony w umowie z 16 sierpnia $1945 \mathrm{roku}^{10}$. Zgodnie z art. 2 umowy granica ta miała przebiegać od punktu położonego około 0,6 kilometra od źródła rzeki San i dalej jej biegiem (środkiem nurtu) do punktu położonego na południe od miejscowości Solina, dalej na wschód od Przemyśla do rzeki Sołokija i dalej jej biegiem i wzdłuż rzeki Bug w kierunku na Niemirów-Jałówkę do zbiegu granic Polski, Litewskiej Socjalistycznej Republiki Radzieckiej i Prus Wschodnich, pozostawiając Grodno po stronie radzieckiej. Ustalony w powyższy sposób przebieg granicy polsko-radzieckiej został zmodyfikowany w latach pięćdziesiątych na mocy cesji wzajemnej. Otóż w roku 1951 oba państwa dokonały wzajemnej zamiany terytorium o powierzchni około 480 kilometrów kwadratowych ${ }^{11}$.

Warto podkreślić, iż granica polsko-radziecka to również granica wzdłuż linii przebiegającej na odcinku od punktu na wschodnim wybrzeżu Zatoki Gdańskiej do punktu wskazanego wyżej zbiegu granic RP, ZSRR i Litewskiej Socjalistycznej Republiki Radzieckiej. Patrząc na mapę Polski okazuje się zatem, iż granica polsko-radziecka to zarówno wschodni, jak i północny odcinek polskiej granicy państwowej. Co ciekawe, w zakresie ostatecznego przebiegu północnego odcinka polskiej granicy państwowej cytowana umowa z 1945 roku (art. 3) odwoływała się do przyszłych uregulowań pokojowych z Niemcami. Przebieg tego odcinka granicy polsko-radzieckiej został ostatecznie wytyczony w roku 1957. Na mocy podpisanej wówczas

$9 \quad$ K. Skubiszewski, Polska granica zachodnia w świetle traktatów, Poznań 1975.

10 Umowa między Rzeczpospolita Polska a Zwiazkiem Socjalistycznych Republik Radzieckich o polsko-radzieckiej granicy państwowej, Dz.U. z 1947 r. Nr 35, poz. 167.

11 Umowa pomiędzy Rzeczpospolitą Polską a Związkiem Socjalistycznych Republik Radzieckich o zamianie odcinków terytoriów państwowych, podpisana dnia 15 lutego 1951 r., Dz.U. z 1952 r. nr 11, poz. 63. 
umowy dwustronnej ${ }^{12}$ wskazany w 1945 roku przebieg granicy polsko-radzieckiej w części przylegającej do Morza Bałtyckiego został w sposób szczegółowy ustalony i potwierdzony.

Status ustalonej w ten sposób granicy polsko-radzieckiej od lat pięćdziesiątych $\mathrm{XX}$ wieku uległ przynajmniej dwóm istotnym zmianom.

Przede wszystkim należy podkreślić, iż wydarzenia schyłku lat osiemdziesiątych i początku lat dziewięćdziesiątych doprowadziły do rozpadu ZSRR. Republiki radzieckie uzyskały niezależność, zaś następca prawnym (sukcesorem) ZSRR stała się Rosja (Federacja Rosyjska). W konsekwencji granica polsko-radziecka stała się - na poszczególnych jej odcinkach - granicą polsko-ukraińską, polsko-białoruską, polsko-litewską oraz polsko-rosyjską. W wymiarze geograficznym dzisiejsza granica Polski z Rosją uległa znacznemu skróceniu w porównaniu do granicy polskoradzieckiej i obejmuje obecnie fragment polskiej granicy państwowej na północnym skraju terytorium (granica z Obwodem Kaliningradzkim o długości około 210 kilometrów ${ }^{13}$ ). Trudno zatem utożsamiać wschodnią granicę Polski z granicą polsko-rosyjską.

Co więcej, wraz z rozwojem aspiracji europejskich Polski i jej bezpośrednich sąsiadów oraz ostatecznym przystapieniem do Unii Europejskiej (1 maja 2004 roku), zmianie uległ status polskiej granicy państwowej na określonych jej odcinkach. Granica polsko-litewska (podobnie jak granica polsko-czeska, polsko-słowacka i polsko-niemiecka) to granica wewnętrzna UE. Granica polsko-białoruska i polsko-ukraińska (granica wschodnia) oraz polsko-rosyjska to obecnie także granica zewnętrzna Unii Europejskiej. Konsekwencje tego faktu sygnalizowano wyżej. W kolejnym punkcie wskazane zostaną najważniejsze elementy unijnego reżimu granicznego odnoszące się do funkcjonowania granicy polsko-rosyjskiej.

\section{Funkcjonowanie granicy polsko-rosyjskiej - wybrane aspekty}

Granica polsko-rosyjska wraz z przystapieniem Polski do Unii Europejskiej stała się granicą zewnętrzną UE. Konsekwencje prawne owego faktu przedstawiono w punkcie 2 i 3 niniejszego opracowania. Warto w tym miejscu przedstawić wybrane regulacje prawa wtórnego Unii, których wpływ na funkcjonowanie polsko-ro-

\footnotetext{
12 Umowa pomiędzy Polską Rzeczpospolitą Ludową a Związkiem Socjalistycznych Republik Radzieckich o wytyczeniu istniejącej polsko-radzieckiej granicy państwowej w części przylegającej do Morza Bałtyckiego, podpisana w Moskwie dnia 5 marca 1957 r., Dz.U. z 1958 r. nr 37, poz. 166. 
syjskiej granicy państwowej podkreśla jej charakter jako granicy zewnętrznej UE ${ }^{14}$. Zwrócimy uwagę na kwestie polityki wizowej oraz pewnych ułatwień w przekraczaniu granicy polsko-rosyjskiej jako granicy zewnętrznej UE (mały ruch graniczny).

Przede wszystkim warto zauważyć, iż pewne zasady dotyczące funkcjonowania polskich granic państwowych jako przyszłych granic zewnętrznych UE wprowadzono jeszcze przed przystapieniem Polski do UE. Stanowiło to element procesu dostosowywania prawa polskiego do standardów unijnych, warunkującego sam akt akcesji. Już w swym stanowisku negocjacyjnym Polska potwierdziła, iż w obszarze „Wymiar Sprawiedliwości i Sprawy Wewnętrzne” zamierza przyjąć i wdrożyć wspólnotowy dorobek prawny i nie będzie wnosić w tym zakresie o okresy przejściowe $^{15}$. W ramach dostosowywania polityki wizowej do systemu unijnego koniecznym stało się wypowiedzenie umów o ruchu bezwizowym w stosunkach z 15 państwami, których obywatele objęci byli obowiązkiem wizowym przy przekraczaniu zewnętrznych granic Unii Europejskiej. Na mocy rozporządzenia Rady (WE) nr 574/1999 z 12 marca 1999 roku ${ }^{16}$ wśród państw tych znajdowała się również Rosja. Obowiązek wizowy w stosunkach ze wszystkimi państwami wskazanymi w rozporządzeniu (w tym z Rosją) Polska wprowadziła z dniem 1 października 2003 roku, prawie na rok przed akcesją. Obywatele polscy udający się do Rosji zostali objęci podobnym obowiązkiem. Warto dodać, iż w stosunkach z Rosją wprowadzeniu wiz towarzyszyło ustanowienie - na zasadzie wzajemności - opłat wizowych. Wskazane regulacje pokazuja, iż już na etapie przedakcesyjnych rozwiązań harmonizacyjnych w zakresie polityki wizowej polska granica państwowa nabierała cech zewnętrznej granicy Unii. W tym okresie jednak Polska dysponowała określonym zakresem swobody w zakresie bilateralnego kształtowania relacji granicznych z Rosją. Związana $\mathrm{z}$ wprowadzeniem obowiązku wizowego umowa między Polską a Federacją Rosyjską ${ }^{17}$ była tego dowodem. Mieszcząc się w ramach standardów unijnych (obowiązek wizowy), kwestię samej wysokości opłat wizowych uzależniała od decyzji stron (art. 13 umowy).

Istotne zmiany przyniosło przystapienie Polski do Unii Europejskiej oraz do strefy Schengen - przypomnijmy, iż nie był to ten sam moment.

$14 \quad$ Z racji na założenia redakcyjne, poniższe przykłady odnoszą się głównie do problemu ruchu osobowego na granicy polsko-rosyjskiej.

15 A. Dudzic, Polska w obszarze wolności, bezpieczeństwa i sprawiedliwości UE, (w:) F. Jasiński, K. Smoter (red.), Obszar wolności, bezpieczeństwa i sprawiedliwości Unii Europejskiej. Geneza, stan i perspektywy rozwoju, Warszawa 2005, s. 460-461.

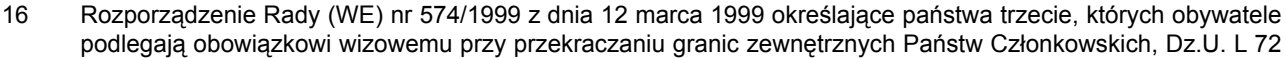
z 18.03.1999. Rozporządzenie to zostało zastapione przez: Rozporządzenie Rady (WE) nr 539/2001 z dnia 15 marca 2001 r. wymieniające państwa trzecie, których obywatele muszą posiadać wizy podczas przekraczania granic zewnętrznych, oraz te, których obywatele są zwolnieni z tego wymogu, Dz U. L 81 z 21.03.2001. Umowa między Rządem Rzeczypospolitej Polskiej a Rządem Federacji Rosyjskiej o warunkach podróży obywateli Rzeczypospolitej Polskiej i obywateli Federacji Rosyjskiej, M.P. z 2003 r. Nr 51, poz. 800. 
Wraz z wejściem w życie Traktatu akcesyjnego ${ }^{18}$ oraz Aktu dotyczącego warunków przystapienia ${ }^{19}$ Polska - już jako członek Unii Europejskiej - stała się związana całością dorobku prawnego Unii ${ }^{20} \mathrm{~W}$ wymiarze prawa pierwotnego, wtórnego oraz podpisywanych przez UE umów międzynarodowych. w tym również umów dotyczących ruchu osobowego na jej granicach zewnętrznych. Członkostwo w Unii przyniosło szereg konsekwencji dla funkcjonowania granicy polskiej na tym jej odcinku, który stał się granicą zewnętrzną UE. Warto przyjrzeć się wybranym przykładom owych konsekwencji.

W maju 2006 roku (25 maja) Wspólnota Europejska (WE) ${ }^{21}$ podpisała z Rosją porozumienie dotyczące ułatwień wizowych ${ }^{22}$. Porozumienie to jednak - wobec wzmiankowanych wyżej reguł w stosunkach polsko-rosyjskich - oznaczało de facto utrudnienia w ruchu osobowym między Polską a Federacja Rosyjską. Zauważmy bowiem, iż umowa zawarta przez WE z Rosją - poza przepisami dotyczącymi dokumentów potwierdzających cel podróży, zasad wydawania wiz wielokrotnego wjazdu, czasu rozpatrywania wniosku wizowego czy przedłużania wiz w okolicznościach wyjątkowych - w art. 6 ust. 1 ustalała wysokość opłaty wizowej na poziomie 35 euro. Była to opłata wyższa od opłaty obowiązującej w relacjach z Rosją na mocy, przywoływanej wyżej, umowy dwustronnej podpisanej w 2003 roku. Warto także wskazać na treść art. 14 umowy między UE i Rosją: Od momentu wejścia $w$ życie niniejsza umowa ma pierwszeństwo wobec postanowień umów lub ustaleń dwustronnych lub wielostronnych zawartych między państwami członkowskimi a Federacja Rosyjska w zakresie, w jakim postanowienia tych umów i ustalen dotyczq zagadnień objętych niniejszq umowa. Postanowienie to potwierdza pierwszeństwo regulacji przyjętej na ,poziomie unijnym” przed ewentualnymi porozumieniami (bilateralnymi czy multilateralnymi) zawartymi przez państwa członkowskie z Rosją w zakresie spraw objętych umową między Unią a Federacją Rosyjską. W ten sposób

18 Traktat między Królestwem Belgii, Królestwem Danii, Republiką Federalna Niemiec, Republika Grecka, Królestwem Hiszpanii, Republiką Francuska, Irlandia, Republiką Włoska, Wielkim Księstwem Luksemburga, Królestwem Niderlandów, Republiką Austrii, Republiką Portugalska, Republiką Finlandii, Królestwem Szwecji, Zjednoczonym Królestwem Wielkiej Brytanii i Irlandii Północnej (Państwami Członkowskimi Unii Europejskiej) a Republiką Czeska, Republiką Estońska, Republiką Cypryjska, Republiką Łotewska, Republiką Litewska, Republiką Węgierska, Republiką Malty, Rzeczpospolitą Polską, Republiką Słowenii, Republiką Słowacką dotyczącego przystapienia Republiki Czeskiej, Republiki Estońskiej, Republiki Cypryjskiej, Republiki Łotewskiej, Republiki Litewskiej, Republiki Węgierskiej, Republiki Malty, Rzeczypospolitej Polskiej, Republiki Słowenii, Republiki Słowackiej do Unii Europejskiej, podpisany w Atenach 16 kwietnia 2003 roku, Dz.U. z 2004 r. Nr 90, poz. 864.

19 Akt dotyczący warunków przystapienia Republiki Czeskiej, Republiki Estońskiej, Republiki Cypryjskiej, Republiki Łotewskiej, Republiki Litewskiej, Republiki Węgierskiej, Republiki Malty, Rzeczypospolitej Polskiej, Republiki Słowenii i Republiki Słowackiej oraz dostosowań w Traktatach stanowiących podstawę Unii Europejskiej, Dz.U. z 2004 r. Nr 90, poz. 864 .

20 Z racji na ograniczoną objętość opracowania pomijam tu kwestie okresów przejściowych w określonych obszarach.

21 Przed wejściem w życie Traktatu z Lizbony Unia Europejska funkcjonowała jako konstrukcja trójfilarowa. Podmiotem formalnie upoważnionym do podpisywania umów międzynarodowych była wówczas Wspólnota Europejska wyposażona w podmiotowość prawa międzynarodowego.

22 Umowa między Wspólnotą Europejską a Federacją Rosyjską o ułatwieniach w wydawaniu wiz obywatelom Unii Europejskiej i Federacji Rosyjskiej, Dz.U. L 129 z 17.05.2007. 
prymat prawa UE został podkreślony. Polska granica z Rosją w coraz pełniejszym stopniu stawała się natomiast granicą zewnętrzną Unii Europejskiej.

W grudniu 2007 roku, na mocy decyzji Rady, Polska została objęta w pełni dorobkiem Schengen ${ }^{23}$. Z polskiej perspektywy był to moment niezwykle ważny - wraz z wejściem decyzji w życie Polska stała się beneficjentem otwarcia granic między państwami członkowskimi. W aspekcie granic zewnętrznych Polski - na odcinkach, które stały się granicą zewnętrzną UE - decyzja Rady oznaczała konieczność ich uszczelnienia ${ }^{24}$. Wiązało się to m.in. ze zniesieniem ograniczeń w stosowaniu systemu informacyjnego Schengen (SIS) czy zasadami wydawania wiz. W tej kwestii - poza wymogami finansowymi - uzyskanie wiz przez obywateli Rosji (lecz również Białorusi i Ukrainy) objęte zostało nowymi, bardziej skomplikowanymi procedurami, co wpłynęło również na czas oczekiwania na wizę.

Obecnie problem przekraczania granic zewnętrznych Unii Europejskiej oraz kwestie wizowe podlegają regulacjom dwóch aktów prawa wtórnego UE - odpowiednio: rozporządzeniu nr 562/2006 Parlamentu Europejskiego i Rady z dnia 15 marca 2006 r. (tzw. kodeks graniczny Schengen) ${ }^{25}$ oraz rozporządzenia Parlamentu Europejskiego i Rady z 13 lipca 2009 roku $^{26}$.

Rozporządzenie ustanawiające kodeks graniczny Schengen jest aktem wprowadzającym brak kontroli granicznych osób przekraczających granice wewnętrzne państw członkowskich UE oraz ustanawiającym zasady podobnej kontroli w odniesieniu do osób przekraczających granice zewnętrzne państw członkowskich. Rozporządzenie definiuje samą granicę zewnętrzną $\mathrm{UE}^{27}$. Określa również zasady przekraczania granic zewnętrznych Unii oraz zasady wjazdu na jej terytorium. Precyzuje kwestie kontroli granic zewnętrznych, w tym również proces odprawy granicznej. W tym aspekcie rozporządzenie zawiera szereg regulacji szczegółowych dotyczących m.in. oddzielnych pasów ruchu czy stemplowania dokumentów podróży. Rozporządzenie zawiera również regulacje dotyczące funkcjonowania granic wewnętrznych UE (definiuje również to pojęcie ${ }^{28}$ ). Warto $\mathrm{w}$ tym miejscu przypomnieć, iż Polska jako członek Unii oraz państwo objęte tzw. dorobkiem Schengen, związana

Decyzja Rady z dnia 6 grudnia 2007 roku w sprawie pełnego stosowania przepisów dorobku Schengen w Republice Czeskiej, Republice Estońskiej, Republice Łotewskiej, Republice Litewskiej, Republice Węgierskiej, Republice Malty, Rzeczypospolitej Polskiej, Republice Słowenii i Republice Słowackiej, Dz. U. L 323 z 08.12.2007. W uproszczeniu jest to jedną z reguł obowiązujących na obszarze Schengen - liberalizacji przepływu osób na granicach wewnętrznych towarzyszy jednoczesne wzmocnienie ochrony (uszczelnienie) granic zewnętrznych UE.

Rozporządzenie (WE) nr 562/2006 Parlamentu Europejskiego i Rady z dnia 15 marca 2006 r. ustanawiające wspólnotowy kodeks zasad regulujących przepływ osób przez granice (kodeks graniczny Schengen), Dz.U. L 105 z 13.4.2006.

26 Rozporządzenie Parlamentu Europejskiego i Rady (WE) nr 810/2009 z dnia 13 lipca 2009 r. ustanawiające Wspólnotowy Kodeks Wizowy (kodeks wizowy), Dz.U. L 243 z 15.09.2009.

27 Art. 2 punkt 2 rozporządzenia: „granice zewnętrzne” oznaczaja granice lądowe, w tym granice na rzekach i jeziorach, oraz granice morskie Państw Członkowskich, a także ich porty lotnicze, porty rzeczne, porty morskie i porty na jeziorach, pod warunkiem, że nie stanowią one granic wewnętrznych. 
jest przepisami rozporządzenia (ze wszystkimi tego konsekwencjami). Jego regulacje będą zatem znajdowały zastosowanie do granicy polsko-rosyjskiej (granicy zewnętrznej Unii).

Rozporządzenie z lipca 2009 roku, ustanawiając Wspólnotowy Kodeks Wizowy, stanowi ujednolicenie reguł dotyczących polityki wizowej Unii Europejskiej. Rozporządzenie ustala tryb i warunki wydawania wiz na tranzyt przez terytorium państw członkowskich lub planowany pobyt na terytorium państw członkowskich nieprzekraczający trzech miesięcy w dowolnym sześciomiesięcznym okresie (art. 1). Zawiera szereg przepisów obejmujących m.in. zasady wydawania wiz łącznie $\mathrm{z}$ tranzytowymi wizami lotniskowymi wraz z określeniem wysokości opłat wizowych. Zasadnicza opłata wynosi 60 euro (art. 16 ust. 1 rozporządzenia), przewidziano jednak szereg odstępstw od tej reguły (np. w wypadku dzieci w wieku od lat sześciu do poniżej lat 12 opłata wynosi 35 euro - art. 16 ust. 2). Przewidziano także zniesienie opłat wizowych względem pewnych kategorii osób (m.in. dzieci poniżej 6 roku życia, uczniów, studentów, uczestników studiów doktoranckich i towarzyszących nauczycieli, którzy podróżują w celu podjęcia studiów lub udziału w szkoleniach czy naukowców z państw trzecich podróżujących w celu prowadzenia badań naukowych - art. 16 ust. 4). Ponownie należy wskazać, iż przepisy rozporządzenia wiążą Polskę i będą znajdowały zastosowanie do ruchu osobowego na granicy polsko-rosyjskiej jako granicy zewnętrznej Unii Europejskiej.

Przykłady unijnych regulacji przywołane wyżej mogłyby sugerować, iż granice zewnętrzne UE stają się barierą stosunkowo trudną do przekroczenia. Z punktu widzenia państw takich jak Polska czynniki społeczne i gospodarcze przemawiają jednak za pewnym stopniem złagodzenia reżimu przekraczania granic zewnętrznych UE. Wydaje się bowiem, iż można zachować pewną równowagę między zapewnieniem bezpieczeństwa granicom zewnętrznym Unii a umożliwieniem właściwych kontaktów transgranicznych z państwami trzecimi. Legislacja unijna wychodzi naprzeciw tego rodzaju potrzebom. Przykładem w tej materii może być instytucja małego ruchu granicznego (MRG), którą warto omówić bliżej.

Mały ruch graniczny został wprowadzony na mocy rozporządzenia Parlamentu Europejskiego i Rady z 20 grudnia 2006 roku $^{29}$. Ustanawia ono zasady małego ruchu granicznego na zewnętrznych granicach państw członkowskich oraz wprowadza w tym celu zezwolenie na przekraczanie granicy w ramach małego ruchu granicznego (art. 1 ust. 1). Państwa członkowskie mogą zawierać (lub utrzymywać w mocy) umowy bilateralne z sąsiadującymi państwami w celu wdrażania MRG (art. 1 ust. 2). Mały ruch graniczny oznacza regularne przekraczanie zewnętrznej granicy 
lądowej przez osoby zamieszkujące strefę przygraniczną ( $\mathrm{tj}$. strefę sięgającą nie dalej niż $30 \mathrm{~km}$ od granicy ${ }^{30}$ ) w celu pobytu w strefie przygranicznej, na przykład ze względów społecznych, kulturalnych lub uzasadnionych powodów ekonomicznych lub ze względów rodzinnych, przez okres nieprzekraczający limitów czasu określonych w rozporządzeniu (art. 3 pkt 3). Przekraczanie granicy odbywa się na podstawie „zezwolenia na przekraczanie granicy w ramach małego ruchu granicznego". Poza posiadaniem zezwolenia warunkiem przekroczenia granicy jest brak wpisu co do danej osoby w Systemie Informacyjnym Schengen (SIS). Osoba ta nie może być również uznana za stanowiącą zagrożenie dla porządku publicznego, bezpieczeństwa wewnętrznego, zdrowia publicznego lub stosunków międzynarodowych żadnego z państw członkowskich.

Rozporządzenie pozostawia państwom członkowskim pewien zakres swobody w kształtowaniu szczegółowych zasad MRG w stosunkach z sąsiadującymi państwami trzecimi (m.in. w odniesieniu do maksymalnego dozwolonego czasu trwania nieprzerwanego pobytu w ramach MRG czy opłat za zezwolenia na przekraczanie granicy w ramach małego ruchu granicznego).

Instytucja małego ruchu granicznego może być postrzegana jako element liberalizujący politykę wizową Unii Europejskiej. Przyjęte przez państwa członkowski i sąsiadujące państwa trzecie zasady MRG mogą ułatwiać ruch osobowy na ich granicach, co ze względu na potrzeby lokalnych społeczności jest niezwykle ważne. Polska podpisała dotąd dwie takie umowy - z Ukrainą ${ }^{31}$ oraz Białorusią ${ }^{32}$, przy czym umowa z Białorusią nie weszła jeszcze w życie. Podobna umowa z Rosją dotyczyć ma Obwodu Kaliningradzkiego i - zgodnie z deklaracjami polskiego Ministra Sprawa Zagranicznych - jest już gotowa. Wolę podpisania umowy wyraża również strona rosyjska. Problemem są postanowienia rozporządzenia dotyczące szerokości strefy przygranicznej (do $30 \mathrm{~km}$ od granicy, z możliwością rozszerzenia do $50 \mathrm{~km}$ ). Regulacja ta powoduje, iż zasięgiem MRG nie zostanie objęty cały Obwód Kaliningradzki, na czym zależy obu stronom. Stąd wspólne działania na rzecz zmiany rozporządzenia w odpowiednim zakresie kierowane przez Polskę i Rosję pod adresem unijnych instytucji (Komisji). Wydaje się, iż w obecnej sytuacji regulacje Rozporządzenia we wskazanym zakresie są ostatnią przeszkodą na drodze do wprowadzenia

30 Jednostki podziału administracyjnego, które mają być uznane za strefę przygraniczna, są określane przez zainteresowane państwa w umowach dwustronnych, o których mowa w art. 13. Jeżeli część którejkolwiek takiej jednostki jest położona między 30 a 50 kilometrem od linii granicy, uznaje się ją mimo to za część strefy przygranicznej - art. 3 pkt 2.

31 Umowa między Rządem Rzeczypospolitej Polskiej a Gabinetem Ministrów Ukrainy o zasadach małego ruchu granicznego, podpisana w Kijowie dnia 28 marca 2008 roku, oraz Protokół, podpisany w Warszawie dnia 22 grudnia 2008 roku, między Rządem Rzeczypospolitej Polskiej a Gabinetem Ministrów Ukrainy o zmianie Umowy między Rządem Rzeczypospolitej Polskiej a Gabinetem Ministrów Ukrainy o zasadach małego ruchu granicznego, podpisanej w Kijowie dnia 28 marca 2008 roku, Dz.U. z 2009 r. Nr 103, poz. 858. zgodę na jej ratyfikację w drodze ustawy z 20 maja 2010 r. Niestety, po stronie białoruskiej podobne procedury nie zostały zakończone. 
MRG w stosunkach z Federacją Rosyjską. Sytuacja ta pokazuje jednak, do jakiego stopnia stosunki graniczne Polski i Rosji zależne są od unijnego ustawodawcy.

\section{Zakończenie}

Przedstawione wyżej uwagi dowodzą, iż wraz z uzyskaniem przez granicę polsko-rosyjską statusu granicy zewnętrznej Unii Europejskiej Polska ma ograniczone pole manewru w zakresie regulowania reżimu granicznego na wskazanym odcinku. W tej mierze prymat posiadają regulacje unijne, które w sposób stosunkowo wyczerpujący określają zasady ochrony granic zewnętrznych UE, zasady jej przekraczania przez obywateli państw trzecich, reguły wizowe. Rozwiązania przyjęte na poziomie unijnym są dla Polski wiążące $i$ - co jest cechą prawa UE - korzystają z pierwszeństwa względem prawa krajowego. W konsekwencji funkcjonowanie granicy polsko-rosyjskiej nie jest zależne wyłącznie od woli obu stron. W wielu kwestiach podmiotem decydującym jest sama Unia Europejska. Pamiętać jednak należy, iż samo ustalanie przebiegu granic państwowych pozostaje kompetencją państw.

Jakkolwiek z perspektywy Unii założeniem podstawowym jest otwieranie (czy wręcz znoszenie) granic w wymiarze wewnętrznym przy jednoczesnym wzmacnianiu ochrony granic zewnętrznych, Unia - co istotne - próbuje uwzględniać specyfikę stosunków granicznych między poszczególnymi państwami oraz potrzeby lokalnej społeczności.

Zauważmy, iż zrozumiałe stają się w tym kontekście restrykcyjne regulacje dotyczące ruchu osobowego czy wymogów wizowych na granicach zewnętrznych Unii. Należy jednak pamiętać, iż towarzyszą im instrumenty wychodzące naprzeciw potrzebom społeczności lokalnych, dla których relatywnie swobodny ruch graniczny w stosunkach z państwami spoza UE ma duże znaczenie - ekonomiczne i społeczne. Przykładem w tej mierze jest instytucja małego ruchu granicznego, która w stosunkach polsko-rosyjskich jeszcze nie obowiązuje jakkolwiek są poważne szanse na jej rychłe wdrożenie. Rozwiązanie w postaci MRG wskazuje, iż mimo dążenia Unii do wzmacniania ochrony granic zewnętrznych, istnieją określone instrumenty umożliwiające pewną liberalizację ruchu granicznego w relacjach z państwami trzecimi. Jest to przykład próby zachowania balansu między wewnętrznym bezpieczeństwem UE a potrzebami (interesami) obywateli Unii zamieszkujących określone obszary przygraniczne. Warto jednak podkreślić, iż instrumenty tego rodzaju są wynikiem działalności ustawodawcy unijnego, a nie efektem samodzielnych porozumień państw członkowskich z państwami trzecimi. 


\section{ПОЛЬСКО-РОССИЙСКАЯ ГРАНИЦА КАК ВНЕШНЯЯ ГРАНИЦА} ЕРОПЕЙСКОГО СОЮЗА

В настоящей работе польско-российская граница представлена, с одной стороны, как пример и вид границы особого типа, существующей между Евросоюзом как международной организацией и государством, не являющимся его членом, а с другой - как основание для раскрытия сути самих внешних границ Евросоюза. В первую очередь проводится анализ природы Евросоюза как специфической международной организации с учетом проблемы ее внутренних и внешних границ. Затем обсуждается способ формирования современной польско-российской границы с акцентом на эволюцию ее характера в связи с постепенной интеграцией Польши с ЕС. Наконец, в последнем разделе рассматриваются отдельные аспекты функционирования польско-российской границы. Этой части работы уделено особое внимание с учетом того, что в ней акцентируется практическое значение функционирования упомянутой межгосударственной границы, служащей одновременно внешней границей особой международной организации, которой несомненно является Европейский Союз. 
THE POLISH-RUSSIAN BORDER AS THE EXTERNAL BORDER OF THE EUROPEAN UNION

In the present study, the Polish-Russian border is treated on the one hand as an example and an illustration of a particular type of border that forms the boundary between the European Union, understood as an international organization, and states from outside the circle of its members. On the other hand, however, it is treated as the basis for an explanation of the substance of the same external borders of the Union. First of all, the nature of the Union as a specific international organization with regard to the issue of its internal and external borders is analysed. Then the way in which the modern Polish-Russian border has evolved is discussed, with a focus on the transformation of its nature in connection with the gradual integration of Poland with the EU. Finally, in the last section, selected aspects of the functioning of the Polish-Russian border are described. Considerable attention has been dedicated to the latter, due to the fact that they highlight the practical dimension of the functioning of the indicated state border, being at the same time the external border of a specific organization, in the form of the European Union.

Key words:

The Polish-Russian border, the European Union, external border, integration, the EU member, Russia 